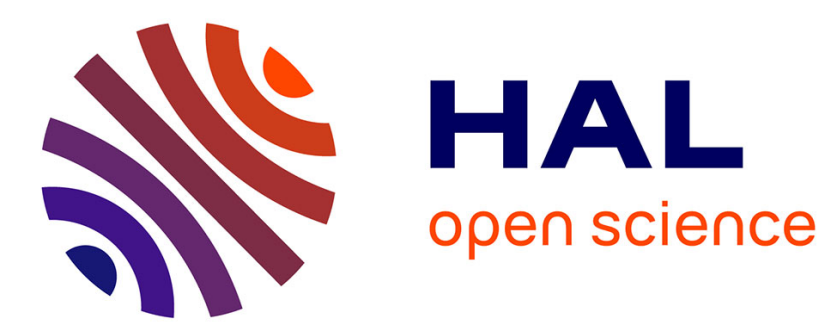

\title{
Matthew Barney, or the body as machine
}

Giovanna Zapperi

\section{To cite this version:}

Giovanna Zapperi. Matthew Barney, or the body as machine. Christiane Hille; Julia Stenzel. Cremaster Anatomies, Transcript Verlag, pp.191-204, 2014, 978-3-8376-2132-7. halshs-01759554

\section{HAL Id: halshs-01759554 https://shs.hal.science/halshs-01759554}

Submitted on 12 Apr 2018

HAL is a multi-disciplinary open access archive for the deposit and dissemination of scientific research documents, whether they are published or not. The documents may come from teaching and research institutions in France or abroad, or from public or private research centers.
L'archive ouverte pluridisciplinaire HAL, est destinée au dépôt et à la diffusion de documents scientifiques de niveau recherche, publiés ou non, émanant des établissements d'enseignement et de recherche français ou étrangers, des laboratoires publics ou privés. 
Matthew Barney, or the body as machine.

Giovanna Zapperi

Published in: Christiane Hille and Julia Stenzel (eds.), Cremaster Anatomies, Berlin, Transcript Verlag 2014, pp. 191-204.

The becoming machine of the body.

I would like to begin by asking the question "What kind of body can art imagine for the future?" In so doing, I will not provide an answer along the lines of "this is the future of the body" or "art is able to see how our bodies will be." Rather, I will focus on the way art has always already imagined the body, responding to cultural and social transformations that affect us as embodied subjects. My objective is to consider this issue through the work of Matthew Barney, an artist who - as the title of this series, Cremaster Anatomies, indicates-has been involved in imaging the body's possible transformations.

Matthew Barney entered the art scene at a very young age. In the early 1990s, he graduated from Yale University. At that time his work dealt mainly with the athletic (male) body. In 1993, the exhibition Post-human helped secure his success. Curated by Jeffrey Deitch, the exhibition's point of departure was the claim that we were entering a post-human era, an era that would radically modify the human body thanks to the increased sophistication of plastic surgery, biotechnologies, and medicine. In his introductory essay, Deitch celebrates these developments by referring to contemporary art and popular culture, explaining that the "extraordinary self-transformation of Ivana Trump (is) an example of a shuffling of reality and fantasy into a reassembled fictional personality that quickly becomes fact"'. Deitch emphasizes art's crucial role in figuring these shifting boundaries of the human. With a mix of demagogy and vulgarization, he maintains, "In the future, artists may no longer be involved in just redefining art. In the posthuman future artists may also be involved in redefining life."

Yet has not art always been concerned in one way or another with the definition and representation of life? The idea that the body could be transformed through technology is one of the most powerful and persistent myths of the western artistic tradition. According to the ancient myth of Pygmalion, art is a response to the desire to create an artificial body that simultaneously resembles and overcomes the natural body. The attraction for creatures born of the encounter

\footnotetext{
${ }^{1}$ Jeffrey Deitch, Post-human, exhib. catalogue, Athens, Deste Foundation of Contemporary Art, and other venues / Ostfildern, Hatje Cantz, 1992 (n. p.)

${ }^{2}$ Idem.
} 
between the human and the artificial has long haunted the artistic as well as the popular imaginary. Before becoming the privileged theme of modern and contemporary science fiction, western culture faced the promise and the threat of becoming-machine. For example, with the historical emergence of new industrial forces and transformations in labor in the $19^{\text {th }}$ century, the possibility of transforming the body became increasingly important. The body was conceived as a mechanism, according to the model of the modern machine. ${ }^{3}$ The figures of the mechanical Other-from Mary Shelley's Frankenstein to Francis Picabia's La fille née sans mère-express the idea that the body, especially since the industrial revolution, is no longer the site of nature and authenticity. Instead, the body is an ambivalent construction, a surface of projection for changing inscriptions. Within this historical framework - whose heritage remains with us today - the body is caught between nature and artificiality.

In the beginning of the $20^{\text {th }}$ century, representations of the interactions between technology and the embodied subject became a recurrent topic in art and popular culture. We could thus draw a line from the avant-garde's "dreams of metalized flesh" - i.e., the metallic becoming of the futurist male body ${ }^{4}$ - up to contemporary visions of techno-bodies. In the context of modernity, the body's transformation into a machine also addresses the question of art in the age of mechanical reproduction, thereby threatening established notions of identity, origin and originality. Accordingly, the incarnations that were labeled "post-human" in the 1990s can be read as a response to the shift from the industrial machine to contemporary communication technologies and biology, from the material to immaterial. It is within this shift that I will situate Matthew Barney's anatomies.

In what follows, I will focus on Barney's conception of the body in his early work and in the Cremaster series. I will not go into a detailed analysis of his work's narrative structure, but rather bracket this aspect of the work in order to more fully concentrate on his imaging of the body. By displacing the abundance of references, quotations, and heroic aspects of the series, I inscribe the work within the historical terrain of late $20^{\text {th }}$ and early $21^{\text {st }}$ centuries' scientific and technological imaginary.

The creative process.

In 1991 Matthew Barney had his first solo exhibitions at the Barbara Gladstone Gallery in New York and Regent Projects in Los Angeles. Each exhibition was inspired by sport imagery,

\footnotetext{
${ }^{3}$ See Anson Rabinbach, The Human Motor. Energy, Fatigue, and the Origins of Modernity, Los Angeles, University of California Press, 1992.

${ }^{4}$ Christine Poggi, Inventing Futurism. The Art and Politics of Artificial Optimism, Princeton, Princeton University Press, 2008, pp. 150-179.
} 
reproducing the space of the gym as a laboratory for the body's constitution. He presented sculptures that made direct reference to gym equipment, while the encounter between the machine and the body was suggested through the use of materials such as Vaseline, wax, tapioca and glucose. At the Barbara Gladstone Gallery, the installation also included a monitor that showed a video of the artist climbing the walls and ceiling of the empty gallery. The performance, Mile High Threshold: Flight with the anal-sadistic warrior, suggests notions of resistance, heroism and physical challenge that strongly implicate sexuality. Moreover, while executing the task, Barney was scantily clothed, wearing only a shower cap and shoes, while metal objects hung close to his body's orifices, thereby emphasizing the performance's erotic implications.

In this early work, Barney plays the role of his first artistic alter ego: the "character of positive restraint". The character is inspired by the famous magician and escapologist Harry Houdini (alias Erich Weiss, 1874-1926), who was able to endure extreme physical situations. The "character of positive restraint" is the protagonist of several of Barney's early performances and remains a central to his later work. Harry Houdini also appears in the Cremaster saga as a protagonist in Cremaster 2 (1999), in which the American writer Norman Mailer plays his role, and again in Cremaster 5 (1995), in which Barney's character clearly suggests Houdini's abilities. What is more, Cremaster 5 tellingly takes place in Budapest, Houdini's hometown. As a crucial figure in Barney's personal mythology, Houdini represents the possibility of overcoming the body's limits. Norman Bryson explains that the "character of positive restraint" represents "a super-athlete with an absolute mastery of external space". 5

At this time, Barney was also interested in another historical figure: the football player Jim Otto. In the years 1960-1975, Otto played for the Oakland Raiders and he was famous for his prosthetic knees. Otto was the perfect prototype of the high-tech athlete whose performance was enhanced through the incorporation of artificial parts into the natural body. The image of a body extended by technology is a powerful fantasy in the sport imaginary: the machine-body represents a fusion of the organic and the mechanical that allows the human body to overcome its natural limitations. In his identification with the athlete, Barney appropriates this machine-body for his own artistic image.

Houdini and Otto represent two different models for surpassing the limits of the body through resistance and control. If Houdini could rely on his mental techniques for the body, Otto used technology in order to achieve a similar goal. As Nancy Spector notes, these two figures are complementary: Houdini is hermetic (i.e., his actions relate to internal forces and inner

\footnotetext{
${ }^{5}$ Norman Bryson, “Matthew Barney’s gonadotropic cavalcade”, Parkett, n. 45, 1995, p. 31.
} 
concentration), while Otto aggressively invades the space around him. ${ }^{6}$ Together they incarnate two sides of the same ambition to overcome the human body's limitations: one proposes a model of self-absorption that could be read as an act of will and omnipotence, and the other proceeds by the desire to posses the outer world. At stake for Barney is thus the creative and artistic possibilities opened up by this struggle.

Houdini is perhaps the more crucial figure given his extreme discipline and control. The notion of the restraint, as the name of his alter ego indicates, is a key element for understanding Barney's conception of the body. Barney developed the parallel between the artist's and the athlete's body in his early performances, which became a starting point for thinking the body as a site of transformation that echoes the creative act. At this time, while still an art student, Barney conducted a series of experimental actions that involved his body. These actions titled Drawing Restraint later became a series of works that included performance, photography, and video - as in, for example, Drawing Restraint 7 (1993) and Drawing Restraint 9 (2006).

In the first of these performative actions in 1988, Barney fabricated a series of physical obstacles in order to transform the act of drawing into a complicated, even painful, experience. In an interview with Jerôme Sans, he explains, "There were these studio experiments, the Drawing Restraint experiments. The first Drawing Restraint consisted of a ramp that were up (sic) two sides of a room and a flexible cord which was strapped around the thighs so that the higher you climbed the more resistance there was. At the top of the ramp different drawing tools were used. It made the act of drawing very difficult." product (i.e., the drawing) remains secondary. At times, the drawings were not even produced due to the unbearable effort involved in their execution. Crucial here is the action's physical implication.

The Drawing restraint experiments represent athletic training as a metaphor for the construction of the artist's body in the creative process. Through these actions, Barney challenged his body while imposing obstacles to overcome his physical limitations. The body is thus constructed as a productive system that strives for potential metamorphoses. Barney, one might say, reproduces what happens in all athletic performances: he performs the need to constantly surpass oneself and go beyond previous achievements. Barney describes this process as a hypertrophic movement for which the ultimate goal is the development of a state of possibility within the body.

Barney's Drawing Restraint series relate to his diagram that illustrates the productive role of the constraint in the creative process. In his diagrammatic explanation the body emerges as a self-

\footnotetext{
${ }^{6}$ Nancy Spector, "In potentia : Matthew Barney / Joseph Beuys", in : Barney / Beuys. All in the present must be transformed, exhib. cat. Berlin, Deutsche Guggenheim / Ostfildern, Hatje Cantz, 2006, p. 27.

${ }^{7}$ Jerôme Sans, "Matthew Barney, héros moderne", Art Press, n. 204, 1995, p. 26.
} 
sufficient, living organism comparable to plants, animals and other living matter. Barney's diagram is composed of three phases. He explains: "I used to think about a three-phase diagram: situation, condition, production. Situation was a zone of pure drive, useless desire that needed direction, needed to be passed through a visceral disciplinary funnel, which was the second zone - condition. The third zone, production, was a kind of anal/oral production of form." 8 Following Barney's (rather obscure) argument, one observes that the body is taken as a given organism, a raw material with which the artist works through restrictive conditions in order to produce form. The diagram makes clear that for Barney the creative process takes place within the body. The early performances collapse the body's struggle in the creative act and the dream of a perfectly functional athletic body. In this way, the athletic metaphor is largely instrumental: what is at stake is the correspondence between control over the body and a sort idealization of the self.

In modernity the figure of the athlete has been historically constructed as a symbol of ideal beauty and as a masculine norm. Barney's reference to this specific male figure indicates that the athletic metaphor evokes the correlation between control over the body and self-transformation into an ideal image. Moreover, his early self-experiments involve not only creativity but also sexuality: the eroticization of the artist's body is highly present in his creative process, as Flight with the analsadistic warrior indicates. Indeed, sexuality occupies a central role within the interaction of bodily functions and resistance. The history of modern sport clearly shows that the need to control the body is primarily enacted against the sexual drives, which need to be sublimated through performance. ${ }^{9}$ In his incarnation of the artist-athlete, Barney administers sexuality by way of the diagram, which shows how single actions are located within a productive system. It is precisely through self-control that the artist succeeds in creating a form out of the body. The body is at once the site where the creative process takes place and the privileged instrument for artistic creation.

\section{Under the sign of metamorphosis.}

How does a form develop out of formlessness? Like a pseudo-scientist, Barney observes how form can be created through hypertrophic movement. He explains, "In those works, I was interested in the bodily functions as examples of the creation of a form through body and resistance. In observing the development of the muscle, I was able to establish how a form could be created out of resistance. Those issues concerned the fact that a form can be created from the body, but also how resistance can become something formal."10 Barney further develops the question of "how to create

\footnotetext{
${ }^{8}$ Thirza Nichols Goodeve, "Travels in Hypertrophia. Interview with Matthew Barney", Artforum, May 1995, p. 117.

${ }^{9}$ See George Mosse, The Image of Man. The Creation of Modern Masculinity, Oxford, Oxford University Press, 1998.

${ }^{10}$ Giovanna Zapperi, "Come si crea la forma. Intervista con Matthew Barney", in : V. Valentini (ed.), Le pratiche del video, Rome, Bulzoni, 2003, p. 311.
} 
a form" out of the body in the Cremaster series, which was produced between 1994 and 2002. Here, once again, Barney defines the body as a field to be modified and redesigned. In this five-episode saga, the hero - usually played by the artist - must subject himself to a series of initiation journeys that require enormous physical effort.

The title "cremaster" refers to the muscle that supports the testicles and thus serves as a metaphor for potentiality. Moreover, the "cremaster" is the first sign of male sex in the development of a fetus, and thereby refers to the moment when the undifferentiated body becomes sexually determined. This transitional moment returns obsessively throughout all Barney's work. Despite the evident sexual implications of this conception of the male body, for Barney the cremaster represents above all the threshold at which various possibilities remain available. This is the developmental stage that interests him most and that he metaphorically relates to the creative process.

The Cremaster series is centered on the possible metamorphosis of the human body. For Barney the borders of the body can be constantly redefined (in Houdini fashion) through an act of will: overcoming physical limitations relates to the struggle against the body's biological destiny, a struggle that characterizes the contemporary scientific imagination. The videos' various narrative plots focus on the potentialities embodied by the protagonist, who challenges both human and natural laws. In Cremaster 4 (1994), for example, this challenge is expressed through the body's transformation and through an effort to go beyond sexual difference by maintaining the reproductive apparatus at an intermediate stage.

The various protagonists in Cremaster are typically characterized by a relentless will that leads them to challenge the conditions that determine their existence. Rather than real characters, the protagonists are revealed as abstract figures that lack psychological complexity in their relentless pursuit of their goals. Their mechanical actions and ambition translates into a will to power that elevates them above the human. In this way, Barney constructs a heroic image of the artist, recalling ancient ideas of art's ambition to overcome nature. The different bodies that appear in the Cremaster series suggest that their biological structure had been radically modified. Here the body emerges as an imaginary construction, suggesting both laboratory experimentation and the performative and eroticized body of the athlete. The Cremaster series' different characters present autonomous organisms that seek to achieve their goals in a masochistic struggle against their own body. Similar to the character of the positive constraint, here the bodies and the drives are entirely involved in the productive effort. 
As is by now well established, Cremaster develops complex narratives, which have been subject to detailed description and analysis ${ }^{11}$. What interests me, however, is less the abundance of references and citations than the repetitive features that resurface in the series. Indeed, Barney's early concerns continue to operate as the driving force for the series' complex and labyrinthine narrative architecture. Crucial for understanding the Cremaster series is the relation between constraint and production, the metamorphoses of the body, and the expression of what Norman Bryson describes as a "will to power" that tirelessly strives to achieve a goal.

If we return to Barney's interest in the fetus's differentiation process, it is striking to observe that his view of the male body corresponds quite precisely to pre-modern theories of the development of the reproductive system. According to Thomas Laqueur, until the $19^{\text {th }}$ century and thus before modern medicine, scientific thought considered the feminine and masculine organs as two versions - i.e., internal and external — of the same apparatus. ${ }^{12}$ Implicit in such a theory was the primacy and autonomy of the male sexual apparatus, while the female was considered a complementary but underdeveloped version that remained inside the body. Barney's conception of bodily development thus implies the centrality of the male body, its autonomy and self-sufficiency.

Throughout the Cremaster cycle metamorphosis is always presented as the ultimate goal, even as it remains in the realm of possibility. The state of potentiality lies more precisely in the tension between titanic ambition and inevitable disaster, whereby the effort to maintain this tension could allow transformation to happen. If Barney's early work involved the body in the productive effort, the Cremaster deploys the body as a tool to affirm the subject against nature's limitations. Also, in Barney's conception of the body-mind dualism, these two categories exist beyond any social or cultural conditioning.

In Cremaster 4 (1994) Barney plays a strange human-goat figure in a narrative that revolves around initiations and physical tests. This figure, the so-called "Laughton Candidate", is a half-man and half-animal who dresses in a fin-de-siècle dandyish style. Key to understanding this figure is the desire to maintain his genital apparatus in an undifferentiated state and thereby overcome sexual difference. In so doing, the figure recalls what happens in the fetus's body before the appearance of the cremaster muscle. This process implies the construction of a body in which opposites coexist: the body is both male and female, human and animal.

In general the bodies that appear in the film are characterized by this state of in-between. The body of the Laughton Candidate suggests manipulation - be it genetic, medical or surgical. By

\footnotetext{
${ }^{11}$ See Naville Wakefield, "The Cremaster Glossary”, in: Nancy Spector (ed.), The Cremaster Cycle, exhib. cat., New York, Solomon R. Guggenheim Museum, 2003.

12 Thomas Laqueur, Making Sex. Body and Gender from the Greeks to Freud, Cambridge, Mass., Harvard University Press, 1992.
} 
surpassing the body's boundaries, he also evokes images of ancient myths and monsters. In addition, the three fairies that follow him along the island of Man - where the narrative takes place - are similarly marked by this in-between status. Yet their feminine identities emerge from their clothes, hairstyle, and postures if not explicitly from their bodies. The three female body-builders that impersonate the fairies also recall the possibility of modifying one's body through exercise and other types of manipulation (e.g., the chemical products that allow muscles to grow uncontrolled). Their androgynous appearance suggests the image of a sexually undifferentiated body and thus the dream of bodily totality and self-accomplishment that is not split into male or female.

While narrative, landscape, and epic construction take on increasing importance in the course of the cycle, the bodies continue to be represented under the sign of metamorphosis. In Cremaster 2, for example, the metamorphosis of the subject is developed through the tragic story of Gary Gilmore's useless search for redemption in death. Gilmore's body is involved in the transformative process only through his death, which means that he fails completely (although death certainly appears as a powerful drive in the entire cycle). In this context, the parallel stories of Gilmore and Houdini indicate a dichotomy between powerlessness and a will to power. Significantly, this parallel involves not only two distinct historical periods, but also two geographic areas that oppose each other as if they were autonomous organisms. To this end, Barney maintains: "It is not an accident that places Fay and Houdini in the fertile vastness of glaciers and Gary in the fragile ecology of a dead lake. Gilmore's terrain is as blasted as the chances he's run out of, while Fay and Houdini occupy a zone that is epic in its potential for metamorphosis.",13

Barney situates metamorphosis in relation to two very peculiar kinds of bodies: the body of Harry Houdini and the body of Fay La Foe, the bee-woman, who constantly - and presumably painfully - trains her waist and in so doing refers to the corset and its oppressive implications. The corset is historically considered as a pre-women's liberation fashion garment, typical of the repressive $19^{\text {th }}$ century, because it constrained the female body into an artificial form. In Cremaster 2 the corset has gone awry: its repressive character has been exaggerated in order to create a new form from the body. In its most literal application, repression produces form, even when —at least in this instance - it no longer looks human. Fay La Foe's body seems to be caught in a process of becoming-insect, as the references to bees suggest. But is this becoming-insect of the woman similar to the becoming-animal of the Laughton Candidate in Cremaster 4 ?

It is perhaps telling that the modified body makes its most spectacular appearance in Cremaster 3, the last episode of the series, and more specifically in the episode called The Order.

\footnotetext{
${ }^{13}$ Richard Flood, "The land of the Everlasting Hills", in: Cremaster 2, exhib cat., Minneapolis, Walker Art Center, 1999.
} 
Filmed at the Guggenheim Museum in New York, The Order sums up the different parts of the cycle and brings together several elements of the series' early conception within its most developed chapter: the hard rock contest, the bunny girls' choreographies, the obstacle race, and the modified bodies. In the third part of The Order the two incarnations of the prosthetic female body suggest a becoming-machine and a becoming-animal. The glass knees and legs of Aimée Mullins, the actress who plays the female character in the film, recall Jim Otto's prosthetic body. Once again, the mutilated body is transfigured into potentiality and overcoming; it is an imaginary and material site where nature (the animal) and technology (the artificial legs) intersect. Moreover, the interaction between the female character and the male protagonist suggests interchangeability between different bodies. In the scene where the two meet, the Entered Apprentice's body (played by Barney) is transformed: he is dressed similar to the woman, and wears a pair of glass sandals that recall the prosthetic nature of her legs.

The bodies in the Cremaster saga are always caught in the process of transformation. They are transformative but not transformed. Thus, what is most disturbing about the various examples described above is the fact that these various becomings never appear as truly liberating. Far from Deleuze and Guattari's notion of becoming as a force that involves desire and subjectivity, these bodies are trapped ${ }^{14}$. Here the transformative potential leads neither to a joyful liberation of the drives nor to a process that involves subjectivities, singularities, and shared experience. The transformation never happens and the process is bound to fail. The forces that are liberated through physical effort are immediately reinvested in the same process, like an endless and useless circle.

\section{Life itself.}

In the Cremaster series body and subjectivity appear as two separate entities, bound to one another through a productive dialectic. Barney's images evoke ancient hubris - i.e., the ambition to go beyond the limits imposed to the humans by the gods. Norman Bryson once remarked that Barney's characters act according to a will to power: "What the will to power seeks is to transcend all limitations in the real and to place nature and the body under the control of its own designs and desires". ${ }^{15}$ In this fantasy of a total control over an organism that is thought in terms of totality and unity, the will to power embodied by the different characters also expresses the artist's ambition.

In his constant preoccupation with "how to create a form", Barney could be considered a sort of hi-tech alchemist. His primary interest in the body indicates a parallel between art and biology, since the modified bodies of his works indicate that both art and biology are concerned with form.

\footnotetext{
${ }^{14}$ Gilles Deleuze and Félix Guattari, A Thousand Plateaus, (1980) trans. Brian Massumi, London, Continuum, 1992, pp. 232-309.

${ }^{15}$ Norman Bryson, art. cit., p. 33.
} 
In the introduction to his 1952 La Connaissance de la vie, French philosopher Georges Canguilhem wrote that life and form go together. To be interested in living matter means to be interested in form: life means formation of forms. ${ }^{16}$ Barney also borrows from modern science the idea that the organism is an undivided, self-contained being, both self-sufficient and subject to inner transformations. As the early performances demonstrate, the artist's studio became a laboratory where the artist carried out complex experiments upon his own body. But, once again, could we say that art, much like science, is an activity that involves observing and experimenting? Canguilhem interestingly points to the link between form and vision in science. He writes, "The living forms are totalities whose meaning lies in the fact that they tend to realize themselves as such [...] they can be captured in a vision, never in a division". ${ }^{17}$ To capture by vision recalls the power of vision to shape the object of the look against the potential loss of coherence and unity.

But how should we interpret this parallel? Is art equal to science; or rather is art's ambition radically distinct? Matthew Barney's personal mythology is founded on the idea of the proximity between art and biology through the use of the body. He thereby suggests that the role of art should be to unveil the secrets of life. The struggle to overcome the body, and thus nature, implies, as we have seen, the possibility to modify its inner biological structure. As Nancy Spector notes, this Promethean ambition is bound to fail ${ }^{18}$; nevertheless, I would like to add that this failure is the necessary condition for representing this ambition as a struggle.

In his representation of the artist as a creator of forms that defy natural laws, Barney shapes a contemporary version of the ancient myths of the artist as demiurge. Barney's grand vision of a future mediated between science and mythology has certainly contributed to his success. His complex and self-referential universe has made it possible to recover a conception of art centered on the figure of the artist as demiurge, capable of modifying his own bodily nature thanks to his imagination. From this perspective, Barney's work re-actualizes a conception of art that dates back at least to the Renaissance.

After the postmodernist deconstruction of the subject, the crisis of artistic mastery, the death of the author, and the feminist critique of artists' masculinity, Barney's success appears as a symptom of the contemporary nostalgia for unity. The ancient myths of art shaped by western society are restored and reconfigured through the operation of foregrounding "creation". As the term "cremaster" indicates, the saga of art also implies a male artistic subject: after all, cremaster contains the word "master". The association between art and science also suggests a restoration of

\footnotetext{
${ }^{16}$ Georges Canguilhem, La connaissance de la vie, (1952), Paris, Vrin, 2003, p. 14.

17 "Les formes vivantes étant des totalités dont le sens réside dans leur tendance à se réaliser comme telles au cours de leur confrontation avec leur milieu, elles peuvent être saisies dans une vision, jamais dans une division", Canguilhem, op. cit., p. 14.

${ }^{18}$ Nancy Spector, "In potentia", op. cit., p. 19.
} 
authority, truth, objectivity and control. But when watching Barney's films, their monstrous bodies and intricate narratives, one is sure to notice that this authority has gone awry. The "cremaster anatomies" are fascinating and problematic, reactionary and challenging. In short, they demand historical interpretation. 